\title{
Sensation Seeking and Self-esteem Differences among Illegal Street Racers in Malaysia
}

\author{
Noh Amit ${ }^{1}$ \\ nohamit@ukm.edu.my
}

Rozmi Ismail2

rozmi@ukm.edu.my

\section{Norhayati Ibrahim ${ }^{1}$}

yatieibra@ukm.edu.my

Zaini Said ${ }^{1}$

zaini@medic.ukm.my

\section{Shazli Ezzat Ghazali1}

shazli_ezzat@ukm.edu.my

\author{
${ }^{1}$ Health Psychology Programme, Faculty of Health Sciences, Universiti Kebangsaan Malaysia \\ Jalan Raja Muda Abdul Aziz, 50300 Kuala Lumpur, Malaysia \\ 2 School of Psychology and Human Development, Faculty of Social Sciences and Humanities \\ Universiti Kebangsaan Malaysia, Bangi, Selangor, Malaysia
}

\section{Doi:10.5901/mjss.2016.v7n1s1p96}

\section{Abstract}

\begin{abstract}
Although illegal (motorcycle) street racing is alarming, little is known about the age, educational and psychological characteristics of these illegal (motorcycle) street racers (mat rempit). Therefore, the aim of this research is to examine the age, educational and selected psychological characteristics of mat rempit in Malaysia. This cross-sectional research was carried out with 197 mat rempit who participated in the Centre for Empowering Youth (Pusat Pemerkasaan Remaja—PERKASA) intervention program. A set of survey questionnaire which comprises of demographic information and measure of sensation seeking and self-esteem were administered. The correlation analysis and a series of one-way ANOVAs were carried out. The correlation analyses showed that there was a strong positive correlation between sensation seeking and global sensation. While impulsivity was strongly correlated with global sensation, impulsivity was having low positive correlation with mild offence. The ANOVA analysis showed that there was no significant difference on sensation seeking, impulsivity, global sensation, self-esteem based on different age groups. However, the only significant difference was reported on impulsivity based on education level differences. Further analysis with Tukey post hoc test showed that the significant difference on impulsivity was found between primary education group and upper secondary education group. The strong correlation between sensation seeking and global sensation has the potential to guide researchers in treating these constructs for future research. Knowledge on educational differences has the potential to facilitate understanding of impulsivity among mat rempit in Malaysia context.
\end{abstract}

Keywords: sensation seeking, self-esteem, age, education, illegal street racer, mat rempit

\section{Introduction}

Illegal street racing among young people is a form of risky behavior (Leigh, 1995). In Malaysia, the term illegal street racing locally refers to the act of groups of young men known as mat rempit involving in illegal and risky motorcycle racing. In Malaysia context, mat rempit is a social construct which refer to young men who involve in illegal motorcycle street racing by riding the underbone motorcycles (locally term as kapcai). These young mat rempit tend to perform risky riding behaviors on public roads. These young mat rempit are normally school leavers or those who are still in 
school/college or those who are being unemployed or unskilled workers (Ibrahim, Ismail, Halim, \& Amit, 2015; Ismail, Din, Lee, Ibrahim, Sukimi, \& Hafez, 2013). The illegal street racing is performed on the public road, with illegally modified motorcycles, reckless riding behavior, limited safety equipment, and sometimes tend to ride under influence of alcohol and drugs. The risky riding behaviors are potential to lead to disability and mortality (Isa, Ariffin, Jawia, \& Yeap, 2013; Ismail et al, 2013). Although there is a small prevalence of mat rempit in Malaysia, the negative consequences of mat rempit illegal racing is alarming. This is because mat rempit activity may include unsafe sexual activity, consumption of alcohol and drugs, committing crime related behavior such as snatching 'ragut,' robbery, groups fighting, and vehicle accidents which may cause the risk of disability and/or death to other road users (Ibrahim et al, 2015; Ismail et al, 2013; Shahrazad et al., 2012; Shope, \& Bingham, 2002).

Despite being affected by development process (Ahmad, Ahmad, \& Abdullah, 2009), illegal motorcycle racing among young people in Malaysia is becoming common. At this developmental stage, young men are in the process of identity formation and characterized by high curiosity and sensation seeking and tend to involve in risky behavior (Amit, Hasking, \& Manderson, 2013). At this stage also, peers pressure play an important role in decision making and potentially affecting the process of identity formation and group behavior (Arnett, 2000; Cooper, Wood, Orcutt, \& Albino, 2003; Schulenberg, Maggs, \& Hurellmann, 1997). At this developmental stage young men also experience various transitional and adjustment process. For instance, young men just started leaving the school system, looking for a secure job and majority of them are being unemployed. Therefore, a small numbers of young men utilize their leisure time mingling with friends and to involve in illegal street racing (Nurullah, Makol-Abdul, \& Abd. Rahman, 2012). The problem may increase as mat rempit tend to perceive illegal racing as a form of social activity in group during leisure after working hours and during weekend.

Research on the identification of characteristics of illegal racers in developing countries showed that illegal racers are those of younger age group, from low to moderate educational level, with high sensation seeking, and low selfesteem (Nurullah et al., 2012; Ismail et al, 2013; Shahrazad et al., 2012; Warn, Tranter, \& Kingham, 2004). Age difference may affect young men involvement in risky behavior (Amit et al, 2013; DuRant, Smith, Kreiter, \& Krowchuk, 1999). This may reflect that young people are curious to try and experience new and challenging things including illegal street racing. The education may also affect one's decision to involve in risk taking behavior (Tobler, Komro, Dabroski, Aveyard, \& Markham, 2011). This is because knowledge has the potential to promote awareness on the danger and negative consequences of illegal racing. High education level has the potential to reduce or minimize individuals' involvement in problematic behaviors and increase chances to involve in a healthy behavior compared to involvement in street racing. This means that knowledge has the potential to guide healthy social behavior and direct appropriate planning for future life.

In addition, sensation seeking behavior is an important risk factor for deviant behavior including illegal street racing (Yi, 2012). In a study carried out with students in late high school, polytechnic college and university in New Zealand high levels of sensation seeking is one of the main characteristics of street racing group. The participants' sensation seeking is associated with their involvement in risky street racing (Warn, et al, 2004). In Malaysia Ismail et al (2013) examined sensation seeking and risky riding behaviors among 564 mat rempit. They found that mat rempit are characterized with high sensation seeking compared to those who did not involve in illegal racing. Those who are higher on impulsive sensation seeking also reported high risky driving. This shows that impulsivity is one important components of sensation seeking (Zuckerman, 2002). Individuals with high impulsivity level have the potential to involve in problematic social behavior. This includes the involvement in illegal street racing and crimes or offence.

Besides that, factor such as self-esteem can be considered as a protective factor for deviant or problematic behavior including illegal street racers (D'Zurilla, Chang, \& Sanna, 2003; Yi, 2012). A few local studies had examined self-esteem among illegal street racers in Malaysia. For instance, Nurullah et al (2012) examined self-esteem among illegal street racers in Malaysia. The authors found that male racers higher in self-esteem compared to female racers. In another study Shahrazad et al (2012) examined self-esteem among illegal motorbike racers and normal adolescents in Malaysia. The authors found that normal adolescents had higher self-esteem compared to illegal motorbike racers who reported lower self-esteem. Therefore, self-esteem issue is a major concern among illegal street racers.

Although there are high prevalence of motorcar illegal racers in developed countries such as Australia, the UK, and the USA (Vaaranen, 2002; Vaaranen \& Wieloch, 2004; Warn, et al, 2004), little is known about illegal street racing among motorcyclists who participating in intervention program. As there are limited research on illegal street racing (Vingilis \& Smart, 2009), various research efforts have to be carried out in order to understand mat rempit population, their characteristics and behaviors. For instance, understanding of their age, educational characteristic and psychological profile/personality trait such as sensation seeking and self-esteem which may facilitate a better understanding of mat rempit population. 
Therefore, the objectives of this study are firstly to examine the correlation between sensation seeking, self-esteem and types of offence among mat rempit. Secondly, to examine the age and educational difference on sensation seeking and self-esteem among mat rempit. As the present study is explorative; there is no direction in hypothesizing the nature of the relationship between sensation-seeking behavior and self-esteem. Understanding of the age, education, sensation seeking and self-esteem differences among mat rempit are important in developing prevention and intervention program which will enable to address the psychological needs of the local mat rempit. The findings also have the potential to inform the policy maker about the best possible approach to address issues related to mat rempit in Malaysia context.

\section{Method}

\subsection{Participants}

This cross-sectional study was carried out with 197 mat rempit (Malay males) who participated in 1-6 series of intervention program by Centre for Empowering Youth (Pusat Pemerkasaan Remaja-PERKASA, Universiti Kebangsaan Malaysia [UKM]) at various PERKASA's intervention program camps in Peninsular Malaysia.

In term of demographic characteristics, all of the participants in this study are Malay males. The ages distribution of the study population are 14-17 years old group (55 participants; 28\%), 18-21 years old group (113 participants; 57\%), and, 22-26 years old group (29 participants; 15\%). The distribution of the education levels are Primary Education (46 participants; 23\%), Lower Secondary [PMR] (78 participants; 40\%), and Upper Secondary [SPM and above] (73 participants; 37\%).

\subsection{Instruments}

\subsubsection{Measure of Sensation Seeking: Sensation Seeking Scale-Form V (SSS-V; Zuckerman, 1994)}

The sensation seeking was measured by Sensation Seeking Scale-Form V (SSS-V; Zuckerman, 1994). The Sensation Seeking Scale is the most widely used form of the Sensation Seeking Scale. Although the original scale of SSS-V consists of 40 items with four main subscales (i.e., Thrill and Adventurous, Experience Seeking, Boredom Susceptibility and Disinhibition), however, in the present study the adapted scale was used. The adapted scale comprises of 19 items to measure the sensation seeking level within individuals in certain situations. The Cronbach's alpha reliability coefficients ranged from .85 to .90 for all scales (Zuckerman, 1994). The Cronbach's alpha reliability coefficient for the 19 items of the Sensation Seeking Scale for the current study is high $(a=.79)$. In this research, sensation seeking is defined as a personality trait with a biological basis defined by the "seeking of varied, novel, complex, and intense sensations and experiences, and the willingness to take physical, social, legal, and financials risks for the sake of such experience" (Zuckerman, 1994, p. 27).

\subsubsection{Measure of Self-esteem: Rosenberg Self-esteem Scale (1965)}

This 10 items unidimensional scale measures the global self-esteem of adolescents especially adolescents' global feelings of self-worth or self-acceptance. It requires the respondent to report feelings about the self directly. This scale is scored using a four-point response format namely, 'strongly agree,' 'agree,' 'disagree' and 'strongly disagree.' Fleming and Courtney (1984) reported a Cronbach of .88 for Rosenberg Self-esteem Scale internal consistency. The test-retest correlation is .85 as reported by Silber and Tippett (1965), .82 by Fleming and Courtney (1984; cited in Blascovich \& Tomaka, 1991; Keith \& Bracken, 1996) and the Rosenberg measure correlated .72 with the Lerner Self-Esteem Scale (cited in Blascovich \& Tomaka, 1991). The higher the score indicates higher the self-esteem. The scale was translated into Bahasa Malaysia by using the translation-back translation procedure. In the present research, self-esteem refers to a positive or negative orientation towards oneself and evaluation towards self-worth (Rosenberg, 1965).

\subsubsection{Measure of Types of Offences}

The types of offences were measured by a list of 14 anti-social behaviors which asking the respondents to respond in term of 'Yes (1)' or 'No (0)'; whether they (and their peers) have involved in such behaviors. Items are divided into two categories, namely anti-social behavior which is considered not serious or mild offences (e.g., smoking, skipping school, hanging out, and watching pornographic materials) and severe offences (e.g., sniffing glue, taking drugs, drinking alcohol 
participated in illegal racing, vandalism and damaging public property; involved in gang-robbery, unsafe sex and gambling). The severe offences are considered as something which is potential to lead to serious consequences not only themselves but also to others or public in general. The number of response 'Yes' scored by respondents represents the total score of their involvement in mild offences or severe offences.

\subsection{Statistical analysis}

Firstly the means and SD of sensation seeking, impulsivity, global sensation, and self-esteem across age and education groups were analyzed. Secondly, the correlation analyses were carried out between sensation seeking, impulsivity, global sensation, and self-esteem and types of offences. Lastly, a series of ANOVA were carried out to examine differences on sensation seeking, impulsivity, global sensation, and self-esteem based on age and educational groups.

\section{Results}

This section describes firstly, means and $S D$ of sensation seeking, impulsivity, global sensation, and self-esteem across age and education groups. Secondly, it reports the results of correlation analysis and a series of ANOVA analyses.

As indicated in Table 1, although there is not much difference between age groups in term of means of impulsivity and global sensation, age group (14-17 years old) reported higher means score of sensation seeking $(M=8.30)$ compared to other age groups. Age group (22-26 years old) reported lower means score of self-esteem $(M=16.75)$ compared to other age groups. In term of educational level differences there is not much difference between educational level groups in term of means of impulsivity and global sensation. While Upper Secondary (SPM and Above) scored lower on sensation seeking $(M=7.89)$ compared to other educational levels, the Primary Education level group scored higher mean of self-esteem $(M=19)$ compared to other educational levels groups.

Table 1: The descriptive analysis of demographic and psychological characteristics of Mat Rempit

\begin{tabular}{|c|c|c|c|c|c|c|c|}
\hline \multirow{2}{*}{ Demographic } & \multicolumn{7}{|c|}{ Sensation seeking Impulsivity Global sensation Self-esteem } \\
\hline & $n$ & M & $S D$ & $M S D$ & $M$ & $S D$ & $S D$ \\
\hline \multicolumn{8}{|l|}{$\overline{\text { Age }}$} \\
\hline 14-17 & 55 & 8.30 & 2.09 & 3.301 .57 & 11.61 & 2.98 & 18.033 .59 \\
\hline $18-21$ & 113 & 7.98 & 1.90 & 3.321 .33 & 11.30 & 2.46 & 18.393 .72 \\
\hline $22-26$ & 29 & 7.93 & 1.92 & 3.931 .60 & 11.86 & 3.10 & 16.752 .95 \\
\hline Total & 197 & 8.06 & 1.95 & 3.411 .45 & 11.47 & 2.70 & 18.053 .61 \\
\hline \multicolumn{8}{|l|}{ Education } \\
\hline 1 Primary E & 46 & 8.26 & 1.92 & 3.041 .24 & 11.30 & 2.61 & 19.004 .85 \\
\hline 2 Lower Secondary (PMR) & 78 & 8.11 & 1.93 & 3.281 .46 & 11.39 & 2.73 & 18.083 .21 \\
\hline 3 Upper Secondary (SPM and Above) & 73 & 7.89 & 2.01 & 3.781 .50 & 11.67 & 2.76 & 17.422 .96 \\
\hline Total & 197 & 8.06 & 1.95 & 3.411 .45 & 11.47 & 2.70 & 18.053 .61 \\
\hline
\end{tabular}

Table 2: The correlation between sensation seeking, impulsivity, global sensation, self-esteem and types of offence

\begin{tabular}{|c|c|c|c|c|c|c|}
\hline & Sensation seeking & Impulsivity & Global sensation & Self-esteem & Mild offence 5 & Severe offence \\
\hline Sensation seeking & 1 & $.243^{\text {t* }}$ & $.853^{\text {*t }}$ & $.152^{*}$ & -.075 & .023 \\
\hline Impulsivity & $.243^{* *}$ & 1 & $.713^{*+}$ & -.092 & $.200^{* *}$ & .004 \\
\hline Global sensation & $.853^{* *}$ & $.713^{\text {t* }}$ & 1 & .060 & .053 & .019 \\
\hline Self-esteem & $.152^{*}$ & -.092 & .060 & 1 & $-.232^{* *}$ & .002 \\
\hline Mild offence & -.075 & $.200^{*+}$ & .053 & $-.232^{* *}$ & 1 & $.242^{+*}$ \\
\hline Severe offence & .023 & .004 & .019 & .002 & $.242^{* *}$ & 1 \\
\hline
\end{tabular}

Table 2 shows the correlation between sensation seeking, impulsivity, global sensation, self-esteem and types of offence. While there were a low positive correlation between sensation seeking, impulsivity $(\alpha=.243)$ and self-esteem $(\alpha=.152)$, there are strong positive correlations between sensation seeking and global sensation $(\alpha=.853)$. While impulsivity was strongly correlated with global sensation $(\alpha=.713)$, impulsivity was having low positive correlation with mild offence $(\alpha=.200)$. There was a low negative correlation between self-esteem and mild offence ( $a=-.232)$. Besides that, the 
positive correlation between mild offence and severe offence found to be low ( $\alpha=.242)$.

A series of one-way ANOVA were further carried out to examine the group differences based sensation seeking, impulsivity, global sensation, self-esteem across age and educational groups. Although the results showed that there were no significant differences on sensation seeking, impulsivity, global sensation, self-esteem based on different age groups; the only significant difference was reported on impulsivity based on education level, $[F(2,194)=4.26, p=.01]$. Further analysis of post hoc Tukey test showed that there is a significant difference on impulsivity between Primary education group and Upper secondary education group $(p=.01)$; where participants of Primary education group reported higher impulsivity than participants of Upper secondary education group. However, there was no difference between participants of Primary education group and the Lower secondary education group as indicated in Table 3.

Table 3: Education Groups and Impulsivity based on Tukey's HSD (alpha=.01)

\begin{tabular}{lcc}
\hline Education & \multicolumn{2}{c}{ Impulsivity } \\
\hline \multirow{2}{*}{ Primary education } & Lower secondary education Upper secondary education \\
Lower secondary education & - & $* *$ \\
Upper secondary education & - & - \\
${ }^{*} p<0.01$ & - & - \\
\hline
\end{tabular}

\section{Discussion}

Based on the correlational analysis results, it can be understood that the constructs of sensation seeking (i.e., sensation seeking, impulsivity, and global sensation) are correlated to each other's and representing of global sensation seeking (Zuckerman, 2002). A low positive correlation between impulsivity and mild offence shows that high impulsivity may indicate high potential to be involved in mild offence. This also supports other findings on the prevalence of high impulsivity among illegal street racers in Malaysia (Ismail et al, 2013). A low negative correlation between self-esteem and mild offence indicates that having low self-esteem is highly related to the involvement of mild offence. This also supports other findings on the prevalence of low self-esteem among illegal street racers in Malaysia (Shahrazad et al, 2012).

These results extend literature on the importance of impulsivity and self-esteem in the development of young people. Impulsivity has to be managed by incorporating the appropriate coping skills in order to manage impulsivity among young illegal racers or mat rempit. Without a proper awareness and skills to manage impulsivity young mat rempit are at risk to involve in mild offences which may include risky and problematic behaviors. On the other hand, high selfesteem has to be promoted among young mat rempit in order to facilitate their development and reducing risk to involve in mild offence including other problematic social behaviors. Therefore, self-esteem and impulsivity are important issues to be addressed among mat rempit in Malaysia.

Results of ANOVA analysis showed that the only significance group difference was found on impulsivity based on education levels. Where further analysis showed that there is a significant difference on impulsivity where participants of Primary education group reported higher impulsivity than participants of Upper secondary education group. The difference of impulsivity based on education level could be explained by the importance of education experience has the potential to provide important knowledge, and skills to the individuals. The knowledge and skills have the potential to promote appropriate coping strategies and good mental health among young mat rempit. Knowledge is also potential to promote insight, facilitating individual thinking of right and wrong and guide individual the right way to express emotion and dissatisfaction. Knowledge is also potential to promote healthy social behavior including lack involvement in crimes among young people (Kulbok \& Cox, 2002).

In addition, this finding also reflects that impulsivity could be the antithetical to goal-oriented behavior such as pursuing education among young people. As impulsivity is a part of the individuals' personality trait, impulsivity is potential to affect individuals' behavioral, social, and emotional functioning related to learning process and experience (Spinella \& Miley, 2003). In fact, lower impulsivity is facilitative of enhancing the ability to focus on study and academic performance compared to higher impulsivity. This indicates that level of impulsivity is one of important factors in understanding the educational differences among young people (Merrell, \& Tymms, 2001; Spinella \& Miley, 2003).

Despite the significance difference on impulsivity based on educational groups, other comparisons indicated nonsignificant between sensation seeking, impulsivity, global sensation, self-esteem based on different age groups with age and educational levels. This might be attributed to homogeneity of the participants in this study as majority of them are 
Muslim Malay males (i.e., of the same ethnic and religious group).

\subsection{Limitation and Direction for Future Research}

There are a few limitations of this study. This includes the majority of the participants of the same ethnic and religious background as majority of them are of Muslim Malay males. Majority of them are school leavers and being unemployed. Being unemployed was reported as a motivating factor for illegal street racing (Nurullah et al., 2012). This limits the generalization of these findings. Although this study examined mat rempit population, however the illegal racing behaviors of mat rempit were not assessed. For future research, it is important to examine the nature of sensation seeking among mat rempit based on qualitative approach. The qualitative study may cover the social context of the illegal street racing, the nature of the illegal racing behaviors and the social cognitive assumptions for risky driving behavior among mat rempit. The meaningfulness of future study could be enhanced by comparing mat rempit in an intervention program and with controlled group.

\subsection{Implications and Conclusion}

The current research indicated the importance of impulsivity and self-esteem in understanding of mild offence among mat rempit in Malaysia. The finding shows that the high impulsivity may indicate high involvement in mild offence. Low selfesteem is also highly related to the involvement of mild offence. Besides that, finding also indicates that impulsivity differs across different education levels especially among those of Primary education group who reported higher impulsivity compared to participants of Upper secondary education group.

In prevention and intervention of illegal street racing it is important to address issues related to impulsivity and selfesteem as high impulsivity and low self-esteem are associated with mild offence among mat rempit. Besides that, difference of impulsivity based on education level indicated that education is an important element in reducing impulsivity among mat rempit. Therefore, it is important to instill various social skills among mat rempit not limited to coping and problem solving skills in facilitating a balance development of mat rempit and to facilitate them to live and involve in a healthy social behavior.

\section{References}

Ahmad, Z., Ahmad, N., \& Abdullah, H. (2009). Urbanism, Space and Human Psychology: Value Change and Urbanization in Malaysia. European Journal of Social Sciences, 11(3), 464-470.

Amit, N., Hasking, P., \& Manderson, L. (2013). Demographic factors associated with alcohol use among young men in rural areas of Sarawak. Addiction Research \& Theory, 21 (5), 391-401.

Arnett, J. J. (2000). Emerging adulthood: A theory of development from the late teens through the twenties. American Psychologist, $55(5), 469-480$.

Blascovich, J., \& Tomaka, J. (1991). Measures of self-esteem. In J. P. Robinson, P. R. Shaver, \& L. S. Wrightsman (Eds.), Measures of Personality and Social Psychological Attitudes (Vol. 1, pp. 115-160). California: Academic Press, Inc.

Cooper, M. L., Wood, P. K., Orcutt, H. K., \& Albino, A. (2003). Personality and the predisposition to engage in risky or problem behaviors during adolescence. Journal of Personaliy and Social Psychoogyl, 84(2), 390-410.

D'Zurilla, T. J., Chang, E. C., \& Sanna, L. J. (2003). Self-esteem and social problem solving as predictors of aggression in college students. Journal of Social and Clinical Psychology, 22, 424-440.

DuRant, R. H., Smith, J. A., Kreiter, S. R., \& Krowchuk, D. P. (1999).The relationship between early age of onset of initial substance use and engaging in multiple health risk behaviors among young adolescents. Archives of Pediatrics and Adolescent Medicine, 153(3), 286-291.

Fleming, J. S., \& Courtney, B. E. (1984). The dimensionality of self-esteem. II. Hierarchical facet model for revised measurement scales. Journal of Personality and Social Psychology, 46, 404-421.

Hansen, E. B., \& Breivik, G. (2001). Sensation seeking as a predictor of positive and negative risk behaviour among adolescents. Personality and Individual Differences, 30, 627-640.

Hoyle, R. H., Stephenson, M. T., Palmgreen, P., Lorch, E. P., \& Donohew, R. L. (2002). Reliability and validity of a brief measure of sensation seeking. Personality and Individual Differences, 32, 401-414.

Ibrahim, N., Ismail, R., Halim, M. R. T. A., \& Amit, N. (2015). Personality, High-Risk Activities and Aggressive Behaviour among Illegal Street Racers. Mediterranean Journal of Social Sciences, 6 (5 S1), 527-533.

Isa, M. H. M., Ariffin, A. H., Jawia, Z. M., \& Yeap, T. C. (2013). Factors Contributing to Crash Involvement of Unlicensed Motorcycle Riders in Malaysia. Jurnal Teknologi, 65(2), 61-66.

Ismail, R., Din, N. C., Lee, O. L., Ibrahim, N., Sukimi, F., \& Hafez, M. H. (2013). Sensation Seeking, Aggression and Risk Riding Behaviors among Motorcycle Street Racers in Malaysia, Annual International Conference on Cognitive \& Behavioral Psychology; 
2013, 189.

Keith, L. K., \& Bracken, B. A. (1996). Self-concept instrument: a historical and evaluative review. In B. A. Bracken (Ed.), Handbook of self-concept (pp. 91-170). Canada: John Wiley \& Son, Inc.

Kulbok, P. A., \& Cox, C. L. (2002). Dimensions of adolescent health behavior. Journal of Adolescence Health, 31(5), 394-400.

Leigh, A. (1995). Youth and Street Racing. Current Issues in Criminal Justice, 7(3), 1-8.

Merrell, C., \& Tymms, P.B. (2001). Inattention, hyperactivity and impulsiveness: Their impact on academic achievement and progress. British Journal of Educational Psychology, 71(1), 43-56.

Nurullah, A. S., Makol-Abdul, P. R., \& Abd. Rahman, S. (2012). Gender and Motivations for Street Racing in Malaysia. Journal of Sociological Research, 3(1), 67-79.

Schulenberg, J. E., Maggs, J. L., \& Hurellmann, K. (1997). Negotiating development transitions during adolescence and young adulthood: Health risks and opportunities. In J. E. Schulenberg, J. L. Maggs \& K. Hurellmann (Eds.), Health risks and development transition during adolescence. New York: Cambridge University Press.

Shope, J. T., \& Bingham, C. R. (2002). Drinking-driving as a component of problem driving and problem behavior in young adults. Journal of Studies on Alcohol, 63(1), 24-33.

Spinella, M., \& Miley, W. M. (2003). Impulsivity and academic achievement in college students. College Student Journal, 37(4), 545-549.

Tobler, A. L., Komro, K. A., Dabroski, A., Aveyard, P., \& Markham, W. A. (2011). Preventing the link between SES and high-risk behaviors: "value-added" education, drug use and delinquency in high-risk, urban schools. Prevention Science, 12(2), 211-21.

Vaaranen, H. (2004). The emotional experience of class: interpreting working-class kids' street racing in Helsinki. Annals Of The American Academy Of Political And Social Science, 595, 91-107.

Vaaranen, H., \& Wieloch, N. (2002). Car crashes and dead end careers: leisure pursuits of the Finish subculture of the kortteliralli street racing. YOUNG: Nordic Journal of Youth Research, 10(1), 42-58.

Vingilis, E., \& Smart, R. G. (2009). Street racing: a neglected research area? Traffic Injury Prevention, 10(2), 148-56.

Wan Shahrazad, W. S., Fauziah I., Asmah Bee M. N., Ismail B. (2012). A Cooperative Study of Self-Esteem, Leadership and Resilience amongst Illegal Motorbike Racers and Normal Adolescents in Malaysia. Asian Social Science, 8(8), 61-68.

Warn, J. R., Tranter, P. J. and Kingham, S. (2004). Fast and Furious 3: Illegal street racing, sensation seeking and risky driving behaviours in New Zealand. 27th Australasian Transport Research Forum, Adelaide, 29 September - 1 October 2004.

Yi, C. (2012). The Psychological Well-being of East Asian Youth (Quality of Life in Asia). Dordrecht, NY: Springer Publishing Co. 